\title{
PENGEMBANGAN MODEL KEWIRAUSAHAAN DALAM PENINGKATAN KINERJA PEMASARAN UMKM DINAS KELAUTAN DAN PERIKANAN PROVINSI JAWA TIMUR
}

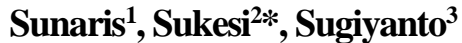 \\ ${ }_{1,2}^{1,2 n i v e r s i t a s ~ D r . ~ S o e t o m o ~ S u r a b a y a ~}$ \\ *Penulis Korespondensi; greenpct17@gmail.com ${ }^{1}$, sukesi@unitomo.ac.id ${ }^{2}$, sugiyanto@unitomo.ac.id ${ }^{3}$
}

\begin{abstract}
Abstrak
UMKM memiliki peran sangat penting dalam pembangunan perekonomian nasional. UMKM dipercaya sebagai pencipta lapangan kerja baru yang diharapkan berdampak kepada berkurangnya pengangguran dan pemerataan pendapatan masyarakat. Selain itu, UMKM telah terbukti mampu bertahan di saat krisis ekonomi terjadi. Tujuan penelitian adalah mendeskripsikan model kewirausahaan yang dimiliki dan yang diperlukan untuk meningkatkan kinerja pemasaran UMKM binaan pada bidang budidaya Dinas Kelautan dan Perikanan Provinsi Jawa Timur. Penelitian ini ialah penelitian kualitatif untuk mengeksplorasi fenomena yang tidak dapat dikuantifikasikan. Hasil penelitian ini menjelaskan bahwa model kewirausahaan UMKM binaan pada bidang budidaya Dinas Kelautan dan Perikanan Provinsi Jawa Timur cenderung masih tradisional dan memiliki beberapa keterbatasan yang menjadi pokok masalah yang yang menghambat pengembangan usaha. Model kewirausahaan yang diperlukan adalah dengan memberikan pengetahuan dengan pembinaan intensif kepada setiap pelaku UMKM terkait teknologi modern sebagai media pemasaran seperti sosial media (misalnya: Facebook, Instagram, Twitter, YouTube) yang mampu mendorong kapasitas penjualan usaha perlu ditingkatkan secara intensif.
\end{abstract}

Kata Kunci: Model ewirausahaan, kinerja pemasaran, UMKM.

\begin{abstract}
MSMEs have a very important role in the development of the national economy. MSMEs are believed to be the creators of new jobs which are expected to have an impact on reducing unemployment and equitable distribution of community income. The research objectives are to describe what entrepreneurial model was owned and needed by MSMEs assisted in the cultivation sector to improve marketing performance. It was qualitative research to explore unquantifiable phenomena. the results of this study explained entrepreneurial model of MSMEs tended to be traditional and had several limitations that hinder business development. It needed to provide knowledge with intensive guidance for each MSMEs actor related to modern technology as a marketing medium such as social media (for example: Facebook, Instagram, Twitter, YouTube) to boost business sales capacity.
\end{abstract}

Keywords: Entrepreneurial model, marketing performance, MSMEs.

\section{Pendahuluan}

Usaha Mikro Kecil dan Menengah (UMKM) memiliki peran sangat penting dalam pembangunan perekonomian nasional. UMKM dipercaya sebagai pencipta lapangan kerja baru yang diharapkan berdampak kepada berkurangnya pengangguran dan pemerataan pendapatan masyarakat. Selain itu, UMKM telah terbukti mampu bertahan disaat krisis ekonomi terjadi. Kemampuannya dalam bertahan disaat banyak usaha besar yang mengalami kebangkrutan, menjadikan UMKM sebagai tulang punggung perekonomian yang mampu menopang kesejahteraan masyarakat. Dengan Jumlah unit usaha yang banyak dan kemampuannya dalam menyerap tenaga kerja memperlihatkan peran stategik UMKM dalam pengentasan kemiskinan dan pendorong kesejahteraan masyarakat.

Salah satu bagian yang penting dari UMKM adalah industri rumahan. Hal tersebut dikarenakan mayoritas usaha kecil dan menengah berawal dari industri rumahan. Industri rumahan atau yang biasa disebut sebagai 
industri rumah tangga merupakan industri padat karya yang berhasil menghasilkan berbagai produk serta menyerap tenaga kerja dalam jumlah yang besar khususnya di daerah pedesaan, sehingga keberadaan industri rumahan sangat berperan penting pada pemerataan pendapatan.

Dinas Kelautan dan Perikanan Provinsi Jawa Timur telah melaksanakan Rapat Pembahasan Kebijakan Pembinaan Pelaku Usaha Pengolahan Hasil Perikanan dengan Tema Membangun Sinergi Pembinaan UMKM Perikanan pada tanggal 30 Januari 2020 bertempat di ruang rapat Nautica I dan II Dinas Kelautan dan Perikanan Provinsi Jawa Timur. Kegiatan ini dihadiri oleh 100 peserta dari kurang lebih 50 instansi dan lembaga yang terdiri dari Dinas Perikanan Kabupaten/ Kota se-Jawa Timur, Akademisi/ Perguruan Tinggi, Lembaga Keuangan, Inkubator Bisnis, Corporate Social Responsibility (CSR) perusahaan/ Rumah Kreatif BUMN, Konsultan Keuangan Mitra Bank (KKMB), Unit Pelaksana Teknis (UPT) Pelatihan Dinas Kelautan dan Perikanan (DKP) Provinsi Jawa Timur, Satuan Kerja Perangkat Daerah (SKPD) Pemerintah Provinsi Jawa Timur terkait, Asosiasi Muslim Pengusaha Umrah dan Haji (AMPUH) Jawa Timur, Forum Industri Kecil Menengah (IKM) dan pegiat pengembangan UMKM. Umari Hasan, Kepala Seksi Pemetaan Usaha dan Investasi perwakilan dari Direktorat Jendral Penguatan dan Daya Saing Kelautan dan Perikanan menyampaikan arah kebijakan dan strategi penguatan daya saing produk Kelautan dan Perikanan tahun 2020. "Ada delapan point arah kebijakan peningkatan Investasi dan Pengembangan Usaha Kelautan dan Perikanan yang di antaranya paling menarik antara lain fasilitasi akses pembiayaan (perbankan dan non-bank), digitalisasi usaha dan pengembangan inkubator bisnis". Ariestya (Penyuluh Perikanan Pelaksana Lanjutan dari Balai Pelatihan dan Penyuluhan Perikanan Banyuwangi) "Proses penerapan strategi dalam pengembangan untuk UMKM juga mendapat perhatian dan dukungan dari penyuluh perikanan diantaranya pendampingan upaya peningkatkan produksi, efisiensi usaha dan info permodalan". Dalam rapat ini juga disampaikan oleh peserta mengenai kendala yang dihadapi dalam pengembangan dan penguatan usaha kelautan dan perikanan antara lain: a) Belum adanya sinkronisasi antara SKP dengan BPOM sehingga lolos SKP belum tentu bisa mendapatkan BPOM b) Sedikit pelaku usaha Kelautan Perikanan memiliki generasi muda untuk meneruskan usaha atau generasi muda untuk memulai usaha baru c) Kelemahan pada manajemen usaha UMKM meliputi manajemen keuangan, produksi dan manajemen pemasaran yang belum tercatat dengan rigid d) Belum ada akses dengan perguruan tinggi untuk pengembangan UMKM Kelautan dan Perikanan e) Kebutuhan pembinaan dan perhatian untuk pengembangan Inkubator Mina Bisnis Provinsi Jawa Timur. Jajaran akademisi dan perguruan tinggi seperti Universitas Airlangga dan Universitas Brawijaya mendukung UMKM dengan program pengabdian masyarakat di lingkup lokal, regional dan nasional untuk membina desa, UMKM dan kelompok masyarakat mandiri. Imbuh Agus Tumulyadi (Universitas Brawijaya) bahwa kegiatan ini seiring dengan program pemerintahan dalam mengembangkan UMKM menjadi mandiri. "Kami membuka peluang kerjasama bidang Kelautan dan Perikanan" tutur Kumala, perwakilan Universitas Ciputra, Koordinator Sosial Entrepeneur. Akses permodalan untuk UMKM produktif dapat mengakses fintech yang telah terdaftar dalam Otoritas Jasa Keuangan (OJK)

Permasalahan pemasaran yang terjadi meliputi tingginya tingkat persaingan, belum terdapatnya merek dan toko sendiri, lemah dalam tawar menawar harga, serta informasi dan wawasan mengenai pasar yang terbatas. Di sisi lain, skala usaha industri rumahan yang produksinya terbatas pada pesanan dan usaha yang masih bersifat individu memberikan kontribusi pada lemahnya pemasaran. Lemahnya inovasi produk, keterbatasan modal, kemampuan pelaku usaha dan jiwa wirausaha yang masih rendah juga memeengaruhi cakupan pemasaran produk. Untuk menyelesaikan permasalahan pemasaran tersebut, dibutuhkan metode dan strategi pemasaran yang tepat. Salah satu pendekatan yang saat ini muncul dalam penerapan pemasaran produk oleh pelaku usaha kecil menengah adalah entrepreneurial marketing. Konsep Entrepreneurial Marketing merupakan peran entrepreneurial yang muncul pada pelaku usaha skala kecil atau pelaku usaha yang baru memulai bisnisnya (Stokes, 2000). Entrepreneurial Marketing merupakan konsep yang lebih sesuai ditinjau dari keterbatasan sumber daya dan permasalahan yang ada pada UMKM. Kinerja pemasaran merupakan sebuah peubah yang dapat digunakan untuk mengukur prestasi pemasaran dari suatu usaha (Stokes, 2000). Hal tersebut sesuai dengan pendapat (Permadi, 1998) yang menyatakan bahwa kinerja pemasaran merupakan konsep untuk mengukur prestasi pasar suatu produk. Kinerja pemasaran merupakan unsur penting dari kinerja perusahaan secara umum karena kinerja suatu perusahaan dapat dilihat dari kinerja pemasarannya (Ismawanti, 2012).

\section{Kajian Teoritis dan Hipotesis Entrepreneurship}

Entrepreneurship adalah orang yang mengorganisir, mengelola dan berani menanggung resiko untuk menciptakan usaha baru dan peluang berusaha (Steinhoff \& Burgess, 1993). Secara esensi pengertian 
entrepreneurship adalah suatu sikap mental, pandangan, wawasan serta pola pikir dan pola tindak seseorang terhadap tugas-tugas yang menjadi tanggung jawabnya dan selalu berorientasi kepada pelanggan. Atau dapat juga diartikan sebagai semua tindakan dari seseorang yang mampu memberi nilai terhadap tugas dan tanggung jawabnya. Selain itu, entrepreneurship adalah kemampuan kreatif dan inovatif yang dijadikan dasar, kiat, dan sumber daya untuk mencari peluang menuju sukses. Inti dari entrepreneurship adalah kemampuan untuk menciptakan seuatu yang baru dan berbeda (create new and different) melaui berpikir kreatif dan bertindak inovatif untuk menciptakan peluang dalam menghadapi tantangan hidup. Pada hakekatnya, entrepreneurship adalah sifat, ciri, dan watak seseorang yang memiliki kemauan dalam mewujudkan gagasan inovatif kedalam dunia nyata secara kreatif.

Pendapat tidak jauh berbeda disampaikan oleh Carre dan Thurik (2003) bahwa entreprenuership merupakan manifestasi kemampuan dan kemauan individual, baik sendiri, dalam tim, di dalam ataupun di luar organisasi untuk menciptakan peluang baru, dan mengenalkan ide mereka ke pasar, dalam upaya menghadapi ketidakpastian dan keterbatasan, melalui pengambilan keputusan lokasi, bentuk dan penggunaan sumberdaya dan lembaga (Carree \& Thurik, 2003). Dari definisi ini dapat dilihat bahwa entrepreneurship merupakan karakteristik perilaku orang, bukan jabatan, ataupun sinonim dari industri kecil

\section{UMKM}

Menurut UU Nomor 9 tahun 1995 ditetapkan bahwa usaha kecil adalah suatu unit usaha yang dimiliki nilai asset netto (tidak termasuk tanah dan bangunan) tidak melebihi Rp 200 juta atau penjualan pertahun tidak lebih besar dari Rp 1 Milliar, milik WNI, berdiri sendiri dan berafiliasi langsung atau tidak langsung dengan usaha menengah atau besar dan berbentuk badan usaha perorangan, baik berbadan hukum maupun tidak berbadan hukum.

Defenisi yang tercantum dalam UU tersebut sebagai dasar dalam mengelompokkan jenis-jenis usaha. Menurut Kementrian Negara Koperasi dan UMKM, kelompok usaha kecil termasuk kelompok usaha mikro. Usaha mikro adalah kegiatan ekonomi rakyat yang bersekala kecil dan bersifat tradisonal dan informal dalam arti belum terdaftar, belum tercatat dan berbadan hukum, dan hasil penjualan tahunan paling banyak Rp 100 juta. Menurut Biro Pusat Statistis/BPS (2005), usaha kecil adalah unit usaha dengan jumlah pekerja paling sedikit 5 orang dan paling banyak 19 orang termasuk pengusaha.

Dalam perekonomian Indonesia Usaha Mikro, Kecil dan Menengah (UMKM) merupakan kelompok usaha yang memiliki jumlah paling besar. Selain itu Kelompok ini terbukti tahan terhadap berbagai macam goncangan krisi ekonomi. Maka sudah menjadi keharusan penguatan kelompok usaha mikro, kecil dan menengah yang melibatkan banyak kelompok. Kriteria usaha yang termasuk dalam Usaha Mikro Kecil dan Menengah telah diatur dalam payung hukum berdasarkan undang-undang.

\section{Entrepreneurial Marketing}

Teori yang mendasari Entrepreneurial Marketing pada dasarnya adalah gabungan dari teori entrepreneurship dan skema teoretisdari disiplin pemasaran. Sehubungan dengan itu, Entrepreneurial Marketing dapat diaplikasikan dalam semua kombinasi yang baik dalam organisasi profit dan non profit (Morris, Schindehutte, \& LaForge, 2002) sehingga muncul istilah social entreprenueurship dan public sector entrepreneurship. Di samping itu, juga dapat diaplikasikan, baik pada organisasi mikro maupun makro. Pada level mikro, Entrepreneurial Marketing, diaplikasikan oleh organisasi secara individu, sedangkan pada level makro dilakukan oleh serangkaian organisasi yang membentuk value added chain, group industry, dan atau aliansi strategis yang terdiri atas berbagai jenis industri.

Mort, Weerawardena, dan Liesch, (2012) menyatakan bahwa ada empat dimensi Entrepreneurial Marketing, yaitu opportunity creation, customer intimacy based innovative products, resource enhancement, dan legitimacy. Se mentara itu, pendapat dari Morris et al. (2002)menyatakan ada tujuh dimensi Entrepreneurial Marketing, yaitu: risk taking, proactivenes, opportunity-focused (opportunity-driven), innovativeness, customer intensity, resource leveraging dan value creation (Morris et al., 2002). Dimensi-dimensi dari tersebut didukung oleh hasil penelitian Miles dan Darroch (2006). Dalam penelitian ini, ada 7 (tujuh) dimensi yang mendasari Entrepreneurial Marketing digunakan, yang merupakan perpaduan antara entrepreneurship dan marketing. Tiga dari dimensi yaitu: pengambilan risiko, proaktif dan fokus pada peluang adalah diambil dari pengertian entrepreneurial orientation (Lumpkin \& Dess, 1996). Dimensi keempat dan kelima yaitu fokus pada inovasi (innovativeness) dan memanfaatkan sumber daya yang juga merupakan dimensi yang ada pada Entrepreneurial Marketing (Morris et al., 2002). Dua dimensi terakhir yaitu intensitas pada pelanggan dan penciptaan nilai 
adalah berkaitan dengan makna market orientation dari perusahaan (Jaworski \& Kohli, 1993). Selanjutnya dijelaskan masing-masing dimensi dalam Entrepreneurial Marketing.

Entrepreneurial Marketing adalah fungsi organisasi dan seperangkat proses untuk menciptakan, mengkomunikasikan dan memberikan nilai kepada pelanggan dan untuk mengelola hubungan pelanggan dengan cara yang menguntungkan organisasi dan yang pemangku kepentingan, dan yang ditandai dengan inovasi, berani mengambil risiko, proaktif, dan mungkin dilakukan tanpa sumber saat ini dikendalikan (Kraus, Harms, \& Fink, 2010).

\section{Kinerja Usaha}

Konsep kinerja bisnis yang sempit terpusat pada penggunaan hasil sederhana berdasarkan indikator keuangan yang diasumsikan mencerminkan pemenuhan ekonomi tujuan perusahaan, konsep ini mengacu pada kinerja keuangan seperti pertumbuhan pasar, profitabilitas, laba per saham. Sementara konsep yang luas dari kinerja bisnis, selain indikator kinerja keuangan juga termasuk indikator kinerja operasional (yaitu, non finansial). Best (2009) mengklasifikasikan kinerja menjadi dua kelompok: kinerja internal (keuangan) dan eksternal Kinerja (marketing).

Samsudin (2005) menyebutkan bahwa kinerja adalah tingkat pelaksanaan tugas yang dapat dicapai seseorang, unit atau divisi dengan menggunakan kemampuan yang ada dan batasan-batasan yang telah ditetapkan untuk mencapai tujuan organisasi/perusahaan.

Namun, sebenarnya kinerja mempunyai makna luas, tidak hanya hasil kerja, tetapi bagaimana proses pekerjaan berlangsung. Adapun pendapat lain yang dikemukakan oleh Armstrong dan Baron dalam (Wibowo, 2018), kinerja merupakan hasil pekerjaan yang mempunyai hubungan dengan tujuan strategis organisasi, kepuasan konsumen, dan memberikan kontribusi pada ekonomi. Venkatraman dan Ramanujam (1986) menunjukkan bahwa kinerja perusahaan merupakan sebuah konstruk multidimensi. Dalam hal ini, kinerja perusahaan terdiri dari kinerja keuangan, kinerja bisnis, dan kinerja keorganisasian. Terdapat dua dimensi dalam kinerja, yaitu internal (kualitas produk, kepuasan pegawai), dan eksternal (lingkungan dan masyarakat).

\section{Metode Penelitian}

Penelitian ini menggunakan pendekatan kualitatif yaitu, metode sebagaimana yang diungkapkan Moleong (2010) sebagai prosedur penelitian yang menghasilkan data deskriptif berupa kata-kata tertulis atau lisan dari orang-orang dan perilaku yang dapat diamati. Untuk itu, dalam penelitian ini peneliti langsung berlaku sebagai alat peneliti utama (key instrument) melakukan proses penelitian secara langsung dan aktif mewawancarai, mengumpulkan berbagai materi, bahan yang dibutuhkan untuk pengembangan model kewirausahaan dalam peningkatan kinerja pemasaran UMKM. Di dalam menentukan informan penelitian, maka peneliti menggunakan penentuan informan secara sengaja (purposive). Menurut Neuman, (2017), purposive sampling adalah teknik pengambilan sumber data informasi dengan pertimbangan tertentu yakni sumber data dianggap paling tahu tentang apa yang diharapkan, dengan keragaman variasi yang ada, bukan pada banyak sampel sumber data. Beberapa kriteria dalam pemilihan informan yang akan diteliti, yaitu:

1. UMKM binaan pada bidang budidaya Dinas Kelautan dan Perikanan Provinsi Jawa Timur.

2. Informan memiliki potensi informasi yang berkualitas dan memiliki pengalaman UMKM lima tahun.

3. Informan mengetahui seluk beluk UMKM.

\section{Analisis Data dan Pembahasan}

Dalam penelitian ini, wawancara dilakukan kepada 10 orang informan yang mewakili 10 UMKM binaan pada bidang perikanan budidaya Dinas Kelautan dan Perikanan Provinsi Jawa Timur. Wawancara dalam penelitian ini dilakukan dengan pertimbangan keterwakilan, kelayakan, aksesibilitas, dan kesediaan. Hasil wawancara kepada informan selanjutnya dianalisis dengan metode koding sebagai dasar dalam menganalisis hasil dan mengambil kesimpulan.

Pengembangan model kewirausahaan dalam penelitian ini dilakukan berdasarkan hasil observasi dan wawancara yang dilakukan pada 10 informan yang mewakili 10 UMKM binaan pada bidang perikanan budidaya Dinas Kelautan dan Perikanan Provinsi Jawa Timur. Dari hasil observasi dan wawancara yang dilakukan menunjukkan bahwa model kewirausahaan yang secara umum diterapkan pada UMKM binaan pada bidang perikanan budidaya Dinas Kelautan dan Perikanan Provinsi Jawa Timur cenderung masih tradisional dan masih memiliki beberapa kendala pokok dalam pelaksanaan usaha. Masalah pokok tersebut meliputi permasalan terkait keterbatasan modal, keterbatasan dalam pemanfaatan sumber daya manusia, keterbatasan akses bahan 
baku, keterbatasan akses pasar, struktur usaha yang masih belum jelas, belum adanya visi dan misi usaha yang jelas, dan kemampuan serta pemahaman terkait pemanfaatan teknologi modern (misalnya: sosial media seperti Facebook, Instagram, Twitter, YouTube, dll) masih sangat minim. Dengan demikian, pengembangan model kewirausahaan yang dapat diajukan dalam penelitian ini berdasarkan kendala pokok tersebut adalah antara lain dengan peningkatan pembinaan secara lebih intensif, pengarahan pembetunkan struktur usaha yang jelas, pengarahan pembangunan visi dan misi usaha yang jelas, penerapan bauran pemasaran (produk, promosi, tempat, dan strategi harga), penerapan segmentation, targeting, positioning, penentuan saluran distribusi, penerapan bauran promosi (termasuk pemanfaatan media sosial secara maksimal untuk periklanan, promo, dll.), dan penjualan yang lebih baik. Bentuk model kewirausahaan yang berjalan saat ini dan gambaran pengembangan model kewirausahaan yang diajukan untuk meningkatkan kinerja pemasaran UMKM binaan pada bidang perikanan budidaya Dinas Kelautan dan Perikanan Provinsi Jawa Timur dalam penelitian ini diilustrasikan pada Gambar 1 .

Gambaran singkat terkait profil UMKM binaan pada bidang perikanan budidaya Dinas Kelautan dan Perikanan Provinsi Jawa Timur dalam penelitian ini dideskripsikan berdasarkan jenis usaha, waktu lama berdirinya usaha, jumlah karyawan yang dimiliki, dan jumlah rata-rata pendapatan per bulan yang dicapai masing-masing UMKM. Berdasarkan data yang diperoleh, UMKM binaan pada bidang perikanan budidaya Dinas Kelautan dan Perikanan Provinsi Jawa Timur memiliki usia atau waktu lama berdiri paling lama yaitu 4,5 tahun, dan memiliki usia atau waktu lama berdiri minimal yaitu 2,5 tahun. Selain itu, tercatat dalam penelitian ini bahwa jumlah karyawan paling sedikit yang dimiliki UMKM binaan pada bidang perikanan budidaya Dinas Kelautan dan Perikanan Provinsi Jawa Timur adalah 3 orang, dan jumlah karyawan paling banyak yaitu sebanyak 12 orang. Terakhir, data yang diperoleh menjelaskan bahwa UMKM binaan pada bidang perikanan budidaya Dinas Kelautan dan Perikanan Provinsi Jawa Timur memiliki pendapatan atau omset per bulan paling banyak mencapai IDR 65.000.000 dan paling sedikit yaitu IDR 32.000.000.

Berdasar hasil wawancara dengan informan, penelitian ini menyimpulkan beberapa permasalahan pokok yang dihadapi oleh UMKM binaan pada bidang perikanan budidaya Dinas Kelautan dan Perikanan Provinsi Jawa Timur antara lain adalah ketersediaan bahan baku, rendahnya akses pasar, kapasitas SDM, dan keterbatasan pengetahuan akan penggunaan media sosial sebaga media pemasaran gratis. Akses pasar antara lain adalah perluasan pasar lokal dalam negeri dan perluasan pasar keluar negeri, disebabkan keterbatasan kemampuan promosi dari usaha yang dijalankan. Ketersediaan bahan baku yang dihadapi oleh UMKM terkait dengan ketersediaan pemasok yang terbatas, harga baku yang fluktuatif, akses bahan baku yang terbatas, dan kemampuan pembelian bahan baku dalam skala besar yang terbatas, sehingga juga berdampak pada harga bahan baku yang tinggi.

Keterbatasan SDM merupakan permasalahan khas yang dihadapi oleh UMKM yang ada di Indonesia. Keterbatasan yang dihadapi antara lain adalah keterbatasan pengetahuan, ketrampilan usaha, dan kapasitas strategik. Di samping itu dalam menjalankan bisnis mayoritas UMKM binaan pada bidang perikanan budidaya Dinas Kelautan dan Perikanan Provinsi Jawa Timur belum memiliki toko online pribadi yang mampu menunjang pemasaran dan penjualan untuk area lokal dalam negeri dan luar negeri sehingga masih relatif kalah dengan bisnis skala besar yang lebih mapan dengan ketersediaan toko online yang mampu menjangkau pasar yang luas. Hal ini menjelaskan bahwa UMKM binaan pada bidang perikanan budidaya Dinas Kelautan dan Perikanan Provinsi Jawa Timur perlu menyediakan anggaran untuk membangun toko online pribadi untuk mendukung kinerja pemasaran yang lebih baik. Kuswiratmo (2016) menjelaskan bahwa usaha Electronic Commerce (E-Commerce) atau lebih dikenal sebutan Online Shopping adalah pelaksanaan perniagaan berupa transaksi penjualan, pembelian, pemesanan, pembayaran, maupun promosi suatu produk barang dan/atau jasa dilakukan dengan memanfaatkan komputer dan sarana komunikasi elektronik digital atau telekomunikasi data. Selain itu, suga diegaskan bahwa bentuk perniagaan UMKM juga dapat dilakukan secara global, yaitu dengan menggunakan jaringan internet.

Hampir semua partisipan mengungkapkan pentingnya pendampingan berlangsung. Hal ini menunjukkan bahwa program pendampingan melalui pembinaan pengembangan usaha termasuk pembinaan penerapan strategi pemasaran dinilai memberikan kemanfaatan bagi UMKM. Namun tidak ada partisipan yang mengungkapkan model pendampingan yang diharapkan mengarahkan pada pentingnya kajian yang lebih mendalam tentang disain program pembinaan yang lebih efektif dan memberikan kemanfaatan bagi peningkatan kinerja pemasaran UMKM. Keterbatasan pengetahuan tentang visi bisnis dan rencana pengembangan bisnis jangka panjang, kemampuan UMKM mendefinisikan pasar dan peluang bisnis serta mengekplorasi potensi sumberdaya alam di wilayah perlu ditingkatkan. Selain itu pengetahuan akan teknologi modern sebagai media 
pemasaran seperti sosial media (misalnya: Facebook, Instagram, Twitter, YouTube, dll.) yang mampu mendorong kapasitas penjualan usaha perlu ditingkatkan secara intensif. Hasil dari penelitian ini sejalan dengan temuan yang diperoleh dalam penelian sebelumnya oleh Achmad et al. (2020) yang menjelaskan bahwa pengetahuan dalam menggunakan dan memanfaatkan media sosial sangat penting bagi UMKM guna membantu meningkatkan kinerja pemasaran, yang pada gilirannya, akan sangat berpengaruh dalam meningkatkan kapasitas penjualan UMKM tersebut. Lebih lanjut, penelitian sebelumnya dari Achmad dan Setiyanti (2015) menjelaskan bahwa media sosial dapat digunakan untuk melakukan komunikasi dalam bisnis, membantu pemasaran produk dan jasa, berkomunikasi dengan pelanggan dan pemasok, melengkapi merk, mengurangi biaya dan untuk penjualan online.

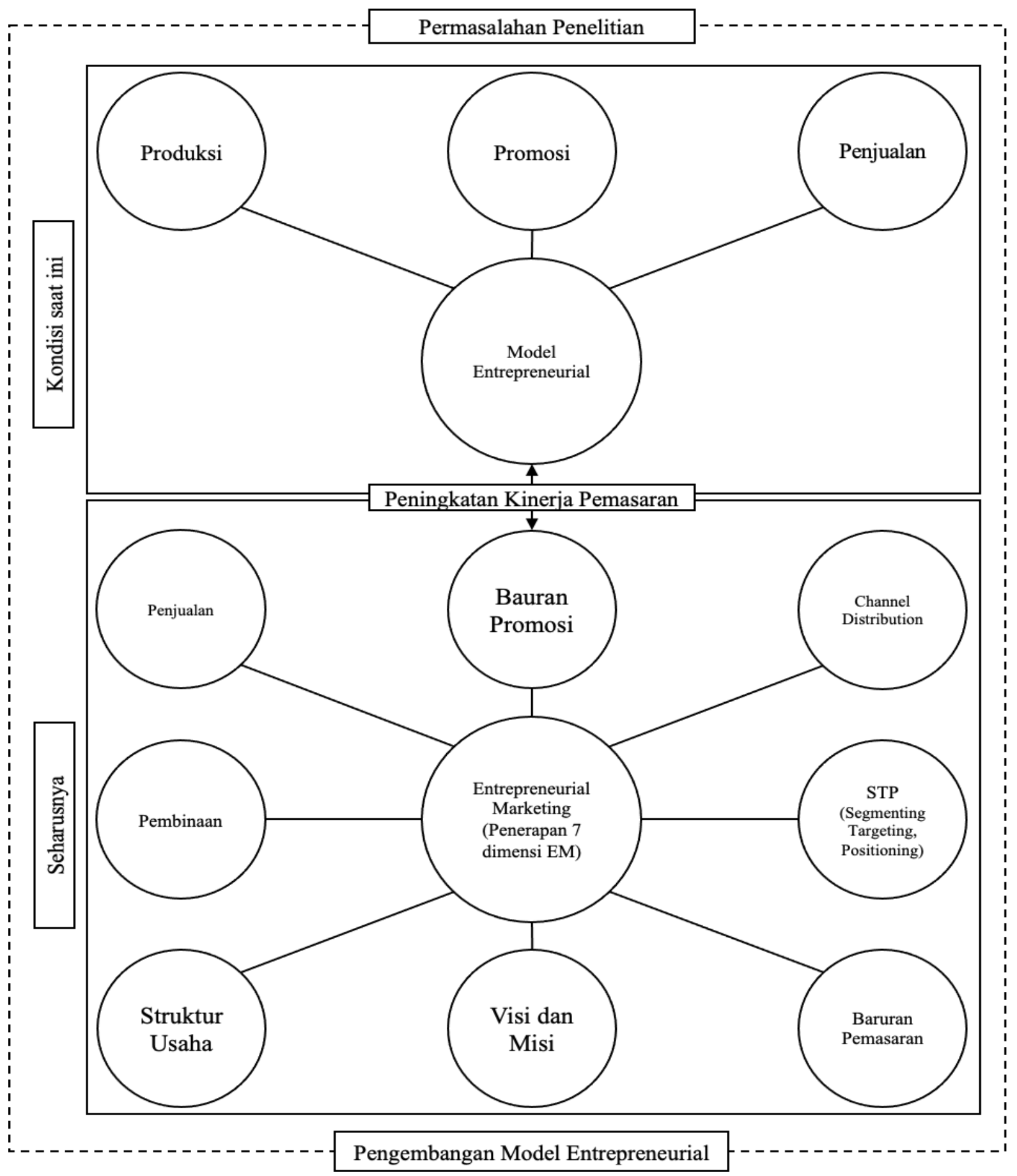

\section{Gambar 1. Pengembangan model}


Program pembinaan pemasaran kewirausahaan perlu diarahkan pada peningkatan kapasitas UMKM dalam mendefinisikan peluang bisnis, memformulasi rencana strategis dan membangun visi usaha secara lebih baik, pengarahan penerapan segmen pasar yang jelas, penentuan saluran distribusi, penerapan bauran promosi (termasuk pemanfaatan media social secara maksimal untuk periklanan, promo, dll.), dan penjualan yang lebih baik sehingga memiliki kekuatan untuk meningkatkan kinerja pemasaran dan memiliki keunggulan untuk bersaing dengan usaha yang lebih mapan. Secara keseluruhan, dapat dijelaskan bahwa temuan dalam penelitian ini sejalan dengan hasil penelitian dari yang menjelaskan bahwa UMKM di Indonesia secara umum menghadapi tingkat kesulitan dalam menghadapi tantangan usaha seperti keterbatasan SDM, pengembangan visi dan misi, penerapan rencana strategis, dan lain sebagainya. Sehingga dalam penelitiannya menegaskan bahwa pandangan strategis ke depan sangat penting untuk diperhatikan bagi setiap UMKM guna mencapai kesuksesan usaha.

\section{Simpulan, Keterbatasan, dan Saran}

Berdasarkan hasil penelitian yang telah dibahas gambaran model kewirausahaan saat ini pada UMKM binaan pada bidang perikanan budidaya Dinas Kelautan dan Perikanan Provinsi Jawa Timur menunjukkan adanya kekurangan dan keterbatasan yang meliputi keterbatasan kapsaitas SDM, pandangan strategis, pengetahuan teknologi modern, dan lain sebagainya, yang pada akhirnya berdampak pada kinerja pemasaran yang tidak optimal. Dengan demikian, pengembangan model kewirausahaan dalam penelitian ini memasukkan beberapa elemen penting yang dapat berdampak signifikan pada peningkatan kinerja pemasaran UMKM. Elemen penting yang harus diperhatikan bagi UMKM binaan pada bidang perikanan budidaya Dinas Kelautan dan Perikanan Provinsi Jawa Timur untuk mengoptimalkan kinerja pemasaran meliputi peningkatan intensitas pembinaan dalam membangun struktur usaha yang jelas, pengembangan visa dan misi usaha, penerapan bauran pemasaran (produk, harga, promosi, dan tempat), penerapan STP (segmenting, targeting, dan positioning), penetapan saluran distribusi yang tepat, pelaksanaan bauran promosi yang baik, dan penerapan strategi penjualan yang tepat.

\section{Simpulan}

Secara detail, kesimpulan yang diperoleh dari hasil penelitian ini dapat dijelaskan, sebagai berikut:

1. Model kewirausahaan UMKM binaan pada bidang perikanan budidaya Dinas Kelautan dan Perikanan Provinsi Jawa Timur cenderung masih tradisional dan memiliki beberapa keterbatasan yang menjadi pokok masalah yang yang menghambat pengembangan usaha. Keterbatasan pokok yang dimiliki mayoritas UMKM binaan pada bidang perikanan budidaya Dinas Kelautan dan Perikanan Provinsi Jawa Timur adalah terbatasnya modal, kesulitan akses bahan baku, keterbatasan SDM, model usaha yang masih belum terstruktur dengan baik, visi dan misi yang belum jelas, keterbatasan akses pasar, keterbatasan media pemasaran, dan kurangnya pengetahuan terhadap media pemasaran yang bisa dimanfaatkan secara gratis.

2. Model Kewirausahaan yang diperlukan UMKM binaan pada bidang perikanan budidaya Dinas Kelautan dan Perikanan Provinsi Jawa Timur untuk meningkatkan pemasaran adalah dengan memberikan pengetahuan dengan pembinaan intensif kedapa setiap pelaku UMKM terkait teknologi modern sebagai media pemasaran seperti sosial media (misalnya: Facebook, Instagram, Twitter, YouTube, dll) yang mampu mendorong kapasitas penjualan usaha perlu ditingkatkan secara intensif. Lebih jauh, diperlukan model kewirausahaan yang terstruktur untuk UMKM binaan pada bidang perikanan budidaya Dinas Kelautan dan Perikanan Provinsi Jawa Timur dengan penerapan sistem pemasaran kewirausahaan yang diarahkan pada peningkatan kapasitas UMKM dalam mendefinisikan peluang bisnis secara lebih baik, memformulasi rencana strategis, serta membangun visi dan misi usaha secara jelas dan lebih baik, pengarahan penerapan STP, penentuan saluran distribusi, penerapan bauran promosi (termasuk pemanfaatan media social secara maksimal untuk periklanan, promo, dll), dan penjualan yang lebih baik.

\section{Saran}

1. Disarankan kepada bidang perikanan budidaya Dinas Kelautan dan Perikanan Provinsi Jawa Timur untuk melakukan evaluasi program pembinaan UMKM guna meningkatkan efektifitas program secara berkesinambungan. Misalnya, dengan memberikan pengetahuan dan pembinaan dalam meningkatkan kapasitas SDM, serta dengan memberikan dorongan pengembangan potensi wilaya melalui pembinaan dalam penguatan pada pemberdayaan SDM yang dimiliki setiap UMKM secara lebih efektif.

2. Memperhatikan hal-hal penting (yang disebutkan dalam pengembangan model kewirausahaan) terkait peningkatan akses bahan baku, peningkatan SDM, penerapan STP, penentuan saluran distribusi, penerapan 
bauran promosi (termasuk pemanfaatan media social secara maksimal untuk periklanan, promo, dll), dan penerapan strategi penjualan yang lebih baik sehingga mampu mengembangkan kapasitas usaha untuk mendongkrak kinerja pemasaran UMKM.

3. Meningkatkan pengetahuan terkait pemanfaatan teknologi modern yang dapat digunakan secara gratis, misalnya media sosial. Dengan pemahaman penggunaan media sosial yang baik, setiap pemilik UMKM dapat melakukan pemasaran secara gratis, efisien, dan efektif.

\section{Keterbatasan}

1. Keterbatasan jumlah informan, sulit ditemukan karna penelitian dilakukan dimasa pandemi, sehingga informasi sangat terbatas.

2. UMKM yang masih dihadapi adalah keterbatasan akses teknologi, dan minimnya pengetahuan teknologi modern yang bisa dimanfaatkan sebagai media pemasaran secara gratis.

\section{Referensi}

Achmad, Z. A., Azhari, T. Z., Esfandiar, W. N., Nuryaningrum, N., Dhilah, A. F., \& Syifana, I. C. (2020). Pemanfaatan media sosial dalam pemasaran produk UMKM di Kelurahan Sidokumpul, Kabupaten Gresik. Jurnal Ilти Komunikasi, 10(1), 17-31.

Achmad, Z., \& Setiyanti, W. O. (2015). The effectiveness of use of soundcloud application for promoting pop punk songs and music. The 3rd Bali International Seminar on Science and Technology (BISSTECH) 2015.

Best, R. J. (2009). Market-based management: Strategy for growing customer value and profitability. New Jersey, NJ: Pearson Education Inc.

Carree, M. A., \& Thurik, A. R. (2003). The impact of entrepreneurship on economic growth. In Z. J.Acs, \& D. B. Audretsch (Eds.) Handbook of entrepreneurship research: An interdisciplinary survey and introduction (pp 437-471). International Handbook Series on Entrepreneurship, vol 1. Boston, MA: Springer. https://doi.org/10.1007/0-387-24519-7_17

Ismawanti, E. (2012). Analisis faktor-faktor yang mempengaruhi kinerja pemasaran dengan faktor lingkungan sebagai variabel moderat (Studi pada industri kerajinan batik di Pekalongan).

Jaworski, B. J., \& Kohli, A. K. (1993). Market orientation: Antecedents and consequences. Journal of Marketing, 57(3), 53-70.

Kraus, S., Harms, R., \& Fink, M. (2010). Entrepreneurial marketing: Moving beyond marketing in new ventures. International Journal of Entrepreneurship and Innovation Management, 11, 19-34.

Kuswiratmo, B. A. (2016). Memulai usaha itu gampang! (1st ed.). Jakarta: Visimedia.

Lumpkin, G. T., \& Dess, G. G. (1996). Clarifying the entrepreneurial orientation construct and linking it to performance. The Academy of Management Review, 21(1), 135-172. https://doi.org/10.2307/ 258632

Miles, M. P., \& Darroch, J. (2006). Large firms, entrepreneurial marketing processes, and the cycle of competitive advantage. European Journal of Marketing, 40(5/6), 485-501. https://doi.org/10.1108/03090560610 657804

Moleong, L. J. (2010). Metodologi penelitian kualitatif. Bandung: PT Remaja Rosdakarya.

Morris, M. H., Schindehutte, M., \& LaForge, R. W. (2002). Entrepreneurial marketing: A construct for integrating emerging entrepreneurship and marketing perspectives. Journal of Marketing Theory and Practice, 10(4), 1-18. https://doi.org/10.1080/10696679.2002.11501922

Mort, G. S., Weerawardena, J., \& Liesch, P. (2012). Advancing entrepreneurial marketing: Evidence from born global firms. European Journal of Marketing, 46(3/4), 542-561. https://doi.org/10.1108/030905612112 02602

Neuman, W. L. (2017). Metodologi penelitian sosial: Pendekatan kualitatif dan kuantitatif (7th ed.). Jakarta: PT Indeks.

Permadi. (1998). Pengembangan konsep market performance. Jurnal Ekonomi Dan Bisnis Indonesia, 13(3).

Samsudin, S. (2005). Manajemen sumber daya manusia. Bandung: Pustaka Setia.

Steinhoff, D., \& Burgess, J. F. (1993). Small business management fundamentals (6th ed.). New York: McGraw-Hill.

Stokes, D. (2000). Putting entrepreneurship into marketing: The processes of entrepreneurial marketing. Journal of Research in Marketing and Entrepreneurship, 2(1), 1-16. https://doi.org/ 10.1108/14715200080001536

Wibowo. (2018). Manajemen kinerja. Rajagrafindo Persada. https://doi.org/978-979-769-130-1. 